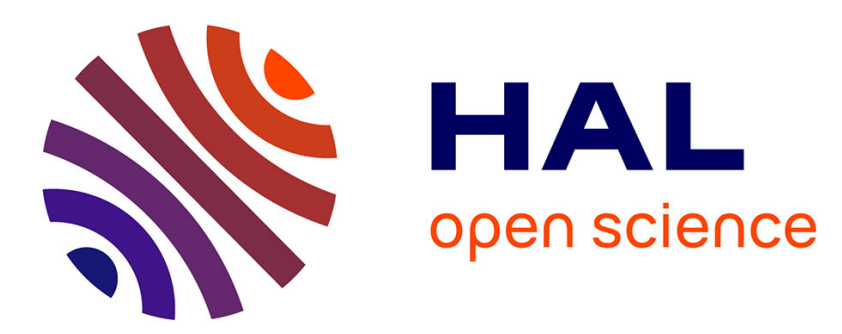

\title{
Contribution of research in reproductive physiology to the culture of tilapias
}

Jean-François Baroiller, Bernard Jalabert

\section{To cite this version:}

Jean-François Baroiller, Bernard Jalabert. Contribution of research in reproductive physiology to the culture of tilapias. Aquatic Living Resources, 1989, 2, pp.105-116. 10.1051/alr:1989013 . hal02728271

\section{HAL Id: hal-02728271 \\ https://hal.inrae.fr/hal-02728271}

Submitted on 2 Jun 2020

HAL is a multi-disciplinary open access archive for the deposit and dissemination of scientific research documents, whether they are published or not. The documents may come from teaching and research institutions in France or abroad, or from public or private research centers.
L'archive ouverte pluridisciplinaire HAL, est destinée au dépôt et à la diffusion de documents scientifiques de niveau recherche, publiés ou non, émanant des établissements d'enseignement et de recherche français ou étrangers, des laboratoires publics ou privés. 


\title{
Contribution of research in reproductive physiology to the culture of tilapias
}

\author{
Jean-François Baroiller ${ }^{(1)}$ and Bernard Jalabert ${ }^{(2)}$ \\ (1) CTFT/CIRAD, Département P'èche et Pisciculture, \\ 45 bis, atenue de la Belle-Gabrielle, 9173 S . logent-sur-.Mame cedex, France. \\ (2) LWRA, Laboraloire de P'hysiologie des Poissons, Campus de Beaulieu, 35042 Rennes cedex, France.
}

Receiver Octolser 13, 1938, accepted February 27, 1989 .

Baroiller J.-F., B. Jalabert. Aquat. Liting Resour., 2, 105-116.

Abstract

Resumé
In confined environments, the precocious reproductive efficiency of "tilapias" (various cichlid species belonging to the genera Orcochromis, Sarotherodon and Tilapia) can rapidly lead to overcrowding and nanism. Therefore, the artificial control of reproduction in these species is very important for success in their culture. Such a control may consist either in completely preventing fry production in a population, in order to improve growth, or in favouring synchronous massive productions of alevins, in order to set up cultures with homogeneous populations.

At present, some of the most intensive techniques arc bascd on the separate rearing of male fish, either after manual sorting or following hormonal inversion treatments leading to monosex populations. New ways of obtaining a male monosex progeny are suggested, based on the viability and fertility of a new genotype YY. Recent data on the scx differentiation of tilapia gonad suggest the possible use of steroids which have been identified in vitro during the early stages of development of the testis and which exhibit high masculinizing potentialities; these studies also suggest the tentative use of specific inhibitors of the activity of some of the cnzymes involved in the synthesis of the above mentioned steroids.

The occurrence of parental care is an important factor in the reproductive cfficiency of tilapias. Recent data show close relationships between the chronology of the mouth-brooding behaviour in Oreochromis, and that of the ovarian eycle. A better knowledge of the underlying physiological factors may facilitate the development of new techniques for the inhibition and/or the synchronization of reproduction.

Keywords: Physiology, reproduction, sexuality, parental care, tilapia culture.

Apport des recherches sur la physiologie de la reproduction à la pisciculture des tilapias.

En milieu confiné, l'efficacité précoce de la reproduction des "tilapias" (diverses espèces de la famille des cichlidés appartenant principalement aux genres Oreochromis, Sarotherodon et Tilapia), conduit à une rapide surpopulation avec une tendance au nanisme. C"est pourquoi le contrôle artificiel de leur reproduction cst trés important pour la réussite de l'élevage. Selon les besoins, un tel contrôle peut consister soit à empêcher complètement la production d'alevins dans une population pour améliorer la croissance, soit à favoriser leur production massive pour la mise en élevage de populations homogènes.

Actuellement, les techniques les plus intensives sont fondées sur l'élevage séparé des mâles, dont le potentiel de croissance est plus important, soit aprés un tri manuel, soit aprés traitement hormonal conduisant à une population monosexe mälc. De nouvelles voies d'obtention de telles descendances monosexes mâles sont proposécs, fondées sur la viabilité et la fertilité d'un génotype nouveau YY. Des travaux récents sur la différenciation du sexe de la gonade de tilapia permettent de suggérer l'utilisation éventuelle de stérö̈des identifiés in titro pendant le dévcloppement testiculaire précoce, et 
présentant de fortes potentialités masculinisantes, ainsi que l'essai d'inhibiteurs spécifiques de certaines activités enzymatiques conduisant à leur synthèse.

L'existence d'un comportement parental est un facteur important de l'efficacité de reproduction des tilapias. Des travaux récents montrent une étroite relation entre la chronologie du comportement d'incubation buccale chez Oreochromis et celle du cycle ovarien. Une meilleure connaissance des facteurs physiologiques sous-jacents devrait nermettre la mise au point de méthodes originales pour inhiber la reproduction ct/ou pour la synchroniser.

Mots-clés : Physiologie, reproduction, sexualité, soins parentaux, pisciculture des tilapias.

\section{INTRODUCTION}

With already more than 20 cultured species (Guerrero, 1982), tilapias belong to a group of Cichlid fish, gencra Oreochromis, Sarotherodon and Tilapia, which is particularly appreciated in the fish-farming activity for its robustness, its wide distribution, its significant growth rate and case of reproduction. This reproductive efficiency directly results from several biological or ethological characteristics:

- The making of a nest combined with a nest protecting behaviour (Lowe-McConnell, 1959; MicBay, 1961; Bruton and Boltt, 1975; Ruwet et al., 1976; Philippart and Ruwet, 1982).

- A sequential oviposition immediatcly followed by the fertilization of each group of ova (Shaw and Aronson, 1954; Philippart and Ruwet, 1982; Mélard, 1986).

- The occurrence of parental care provided to the eggs immediatcly after they have been fertilized. In mouth-brooding species (Sarotherodon and Oreochromis), the eggs are brooded in the buccopharyngeal cavity; this behaviour is often combined with a migration of the brecding fish to a planted and thus protected arca. Substrate-spawning species (Tilapia) ventilate their eggs by constantly stirring the water with their caudal fins (McBay, 1961; Fishclson, 1966; Arrignon, 1969; Rolhbard and Pruginin, 1975; Rothbard, 1979; Ruwet et al., 1976).

- Parental care is also provided after hatching (Ruwet, 1962; Ruwet et al., 1976; Perrone and Zaret, 1979; Owusu-Frimpong, 1987), and lasts at least until the resorption of the yolk vesicle.

- Reproduction may begin quite precociously for small-sized animals (Lowe-McConnell, 1958; 1983; Ruwet et al., 1976). Therefore, under certain conditions, maturation has been observed for $3.8 \mathrm{~cm}$ long Sarotherodon melanotheron (Eyeson, 1983), $4.2 \mathrm{~cm}$ long Oreochromis mossambicus (Arrignon, 1969) and $6 \mathrm{~cm}$ long Tilapia zillii (Dadzie and IVangila, 1980).

- Successive reproduction cycles cnable a female to produce a new batch of fry every 4 to 6 weeks (Arrignon, 1969; Rothbard and Pruginin, 1975; Ruwet et al., 1976; Mélard and Philippart, 1981), except in environments exposed to significant seasonal variations (Moreau, 1979). Under optimal conditions, the relative lack of synchronization between individual breeding females from the same population leads to a continuous fry production.

All these biological characteristics may be responsible for a rapid evolution towards overcrowding and nanism in a confined environment and in a situation of competition for food (Hickling, 1960; McBay, 1961; Loya and Fishelson, 1969; Hyder, 1970; Fryer and Iles, 1972; Bard et al., 1974; Bruton and Allanson, 1974; Eyeson, 1983; Lazard, 1984). Therefore, controlling reproduction should improve the profitability of tilapia culture. As a general trend in fish, methods usually are expected to act on the gonads, by either modulating their development (stimulation or inhibition, temporary or definitive), or preferentially biasing the sex-ratio in favour of the sex which has the best aquacultural potentialities.

For tilapias, these approaches are facilitated by specific characteristics of this group: first, the precocious sexual dimorphism of the urogenital papilla (2-3 months after fertilization) makes it possible to scparate male from female fish just before the very first reproduction. Second, hybridization between certain species results in male monosex progenics.

Thus, all the techniques presented above depend either on the control of gonadal development in order to prevent the production of gametes, or on the separation of the sexes so as to impede fertilization. However, the importance of parental care behaviour in these Cichlids can also suggest new approaches to the practical artificial control of reproduction.

This article reviews the present knowledges regarding the physiological mechanisms of gonadal differentiation and maturation, reproductive behaviour and parental care in tilapias, in relation to practical techniques for the control of reproduction.

\section{HORMIONE INVERSION AND DIFFERENTIA- TION OF THE GONAD'S SEX}

The easiest and most radical means of avoiding reproduction consists in separating male from female fish. For tilapias, it is an accepted fact that male growth is faster than that of female (Pruginin, 1967; Shell, 1967; Hickling, 1968; Lazard, 1980; Hanson et 


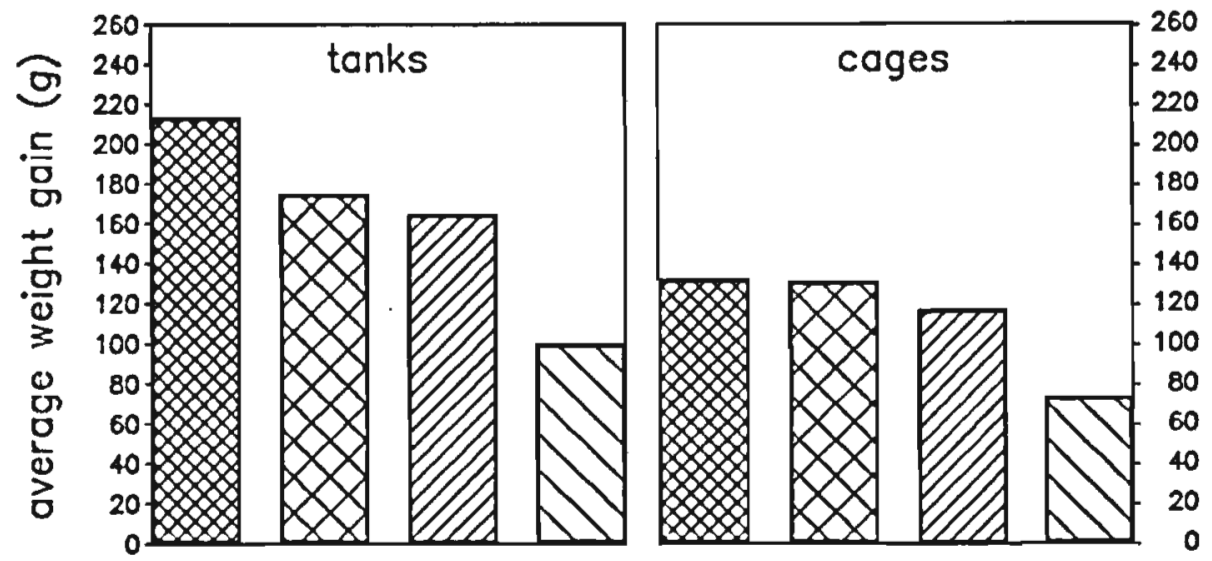

population with mole phenotype but mixed genotype
population with mole phenotype but female genotype
population with mole phenotype and mole genotype
population with femole phenotype and female genotype

Figure 1. - Comparative gronth in tanks or in cages of monovex populations of tilapias (Oreochromis niloticus), phenolypically male or female, but having various kinds of sexual genotype (drawn from data reported by Hanson et al., 1983).

al., 1983; Legendre, 1986). As a matter of fact, Hanson et al. (1983) showed that male populations always have a better growth than female populations ( fig. 1), by using some of the techniques mentioned below. liesides, they observed that the growth potential is equal for male individuals which are genetically female and for animals having a male phenotype and genotype. In practice, male monosex populations can be obtained by manual sexing, hybridization and/or by hormone inversion. This manual sexing according to the urogenital papilla consists in getting rid of all females, i.e. about half of the population. However, this biomass has indeed growth potential which seem equal to those of the male fish population when its phenotype is imposed. Morcover, this sexing can only be carricd out for animals at least 20 to $50 \mathrm{~g}$ weight (Lazard, 1980; Hepher and l'ruginin, 1982; Mélard, 1986). On the other hand, it takes time and labour and diagnosis mistakes can range from 2.7 to $10 \%$ (Lazard, 1980; Chervinski and Rothbard, 1981/1982). As far as hybridization is concerned, it appears very difficult in common practice to maintain very high percentages of male first generation hybrids for commercial production (Pruginin et al., 1975; Lovshin, 1982; Gucrrero, 1982). This cvolution scems to bc due to a progressive contamination, which appears almost unavoidable in commercial fish farm conditions, of domestic brood stocks from cach parcntal species one by the other. On the other hand, possible interspecific incompatibilities seem to account for low reproduction and fertility rates (Lovshin, 1982; Guerrero, 1982; Mires, 1982). On the contrary, the masculinizing hormonal inversion proved to be an efficient and rcliable tool.

\section{Hormonal inversion of the sex}

After Yamamoto's experiments (1953, 1958 and 1969) on the medaka, Oryzias latipes, functional sex inversions have been carried out in numerous species by means of hormone treatments given during carly developmental stages (review by Hunter and Donaldson, 1983).

Whatcrer the species, the casiest method consists of masculinizing a population of tilapia fry by the incorporation of a synthetic steroid in the diet. Although experimental conditions were very heterogeneous (table 1 ), a 100\% efficiency is obtained by numerous authors using this kind of treatment. However, even if this technique appears reliable and simple, there still exists problems linked to the use of hormones on growing animals which are directly intended for marketing (Shelton et al., 1978; Johnstone et al., 1983; Goudic et al., $1986 a$ and $b$ ). The experimental use of radioactively labelled steroids in Oreochromis aurcus shows that the viscera contain $90 \%$ of the total radioactivity present in the fry during the treatment ( $f i g .2$ ); after this treatment had been stopped, the total radioactivity measured in the whole animal decreased by $90 \%$ in 24 hours and by $99 \%$ in 3 weeks (Goudie et al., 1986a). Nevertheless, if the metabolism of synthetic steroids in higher vertebrates follows the same pathways as those taken by equivalent endogenous hormones (Fotherby and James, 1972), the fate of such molecules in fish and the possible effects of their degradation products on the environment are not very well known yct. It is therefore possible to envisage an indirect approach which would avoid these problems. 
Table 1. - Reports of masculinizing treatments (synthetic steroids administered in the food of fry) leading to $100 \%$ male population in tilapia (genus Oreochromis).

\begin{tabular}{|c|c|c|c|c|c|c|c|c|}
\hline Species & $\begin{array}{l}\text { Age or } \\
\text { Size }\end{array}$ & $\begin{array}{c}\text { Dose } \\
\text { (mg,kg) } \\
\text { (in food) }\end{array}$ & $\begin{array}{c}\text { Duration } \\
\text { (days) }\end{array}$ & $\begin{array}{c}\text { Morta- } \\
\text { lity } \\
(\%)\end{array}$ & $\begin{array}{l}\text { Tempe- } \\
\text { rature } \\
\text { ('C) }\end{array}$ & $\begin{array}{l}\text { Percent. } \\
\text { of } \alpha^{\prime} \text { in } \\
\text { controls }\end{array}$ & $\begin{array}{l}\text { Ste- } \\
\text { roid } \\
\text { treat- } \\
\text { ment }\end{array}$ & Authors \\
\hline O. mossambicus & 2 months & 40 & 60 & 47 & 32 to 30 & 56 & MT & $\begin{array}{c}\text { Jalabert et al., } \\
1974\end{array}$ \\
\hline \multirow[t]{3}{*}{ O. niloticus } & $\begin{array}{c}8.5-12 \mathrm{~mm} \\
13.2-20.2 \mathrm{~mm}\end{array}$ & $\begin{array}{c}50,100 \\
100\end{array}$ & $\begin{array}{l}30 \\
30\end{array}$ & & 27 to 30 & 60 to 72 & $\mathrm{MT}$ & $\begin{array}{l}\text { Nakamura } \\
\text { and Iwahashi, } 1982\end{array}$ \\
\hline & $10 \mathrm{~mm}$ & 50 & 28 to 42 & 2 to 53 & & 78 & MT & $\begin{array}{l}\text { Owusu-Frimpong } \\
\text { and Nijjhar, } 1981\end{array}$ \\
\hline & $9-11 \mathrm{~mm}$ & 60 & 21 & $6-22$ & 21 & 56 & ET & Guerrero, 1975 \\
\hline O. hornorum & $9.11 \mathrm{~mm}$ & 30 & 21 or 28 & 0 to 18 & 27 & 53 & MTT & Obi and Shelton, 1983 \\
\hline
\end{tabular}

MT: $17 \alpha-M$ Icthylicstosterone.

ET: 17x-Ethynyltestosterone.

Species with a WZ femalc heterogamety such as $O$. aureus (Guerrero, 1975; Liu, 1977) or O. hornorum (Hickling, 1960; Chen, 1969) represent the easiest case (fig.3): after inversion by means of feminizing hormones, the neo-female fish can be identified rapidly according to the sex ratio of their progeny. As a matter of fact, a neo-female $Z Z$ bred with a non-treated male $\mathrm{ZZ}(a)$ leads to the production of $100 \%$ animals $\mathrm{ZZ}$ of male phenotype; the normal crossbrecding (b) of a female WZ with a non-treated male $\mathrm{ZZ}$ produces $50 \%$ animals of each sex. Inversed individuals $\mathrm{ZZ}$ can thus be isolated in order to be used as brceding fish; when crossed with non-treated male fish of the same species, they shall thus produce male monosex populations.

Concerning the species with a female homogamety XX (fig. 4), such as O. niloticus (Jalabert et al., 1974) or O. mossambicus (Hickling, 1960; Chen, 1969), an additional step is necessary to reach an equivalent result. The progeny of female fish which had been submitted to hormonal treatment during early development can present two types of sex ratios: the first one $(a)$ is normal, composed of $50 \%$ of each sex, coming from animals of female genotype XX. The second one $(b)$ which comprises $75 \%$ male fish and $25 \%$ femalc fish results from the crossbreeding of the neo-female $X Y$ with a non-treated male fish $X Y$. Among these $75 \%$ male fish, there are some $Y Y$ individuals which can be identified by their male monosex progeny during a new test $(c)$. These animals of a new genotype which are viable and fertile (Baroiller et al., unpublished data) can be used as brecding fish producing $100 \%$ malc fish populations at each reproduction with non-treated female fish. Sex inversion by means of hormones thus remains an essential and necessary tool in such indirect approaches of monosexing.

However, the extension of this technique can meet with some difficulties, such as the occurrence of variable results as regards the monosex percentage obtained (Hunter and Donaldson, 1983) and a lesser efficiency of the feminizing treatments when compared to the masculinizing ones (Tayamen and Shelton, 1978; Hopkins et al., 1979). The latter difficulties may suggest either that the hormones which are used may not correspond to those involved in rivo in the differentiation of the gonad's sex (this puts into question the nature of the steroid or even the molecule which must be administered), or that the moment and duration of the treatments may have been chosen inadequately. In fact, no determining physiological proof has been brought so far to support Yamamoto's hypothesis (1969) according to which steroids are natural inducers of the gonadic differentiation. The modification of the natural process of sexual differentiation by exogenous steroids could be due to a pharmacological action, as suggested by Reinboth (1970). If steroids really are the endogenous inducers, which ones are involved?

\section{Gonadal sex differentiation}

Very few works have been performed in gonochoristic fish in order to characterize carly steroidogenetic pathways in the gonad during its differentiation (Salmo gairdneri: Van der Hurk et al., 1982; tilapias: Rothbard et al., 1987, and Baroiller et al., 1988). In O. niloticus (Baroiller, 1988) steroidogenic potentialities have been examined by histochemistry and by in citro studies of metabolism in gonads which 


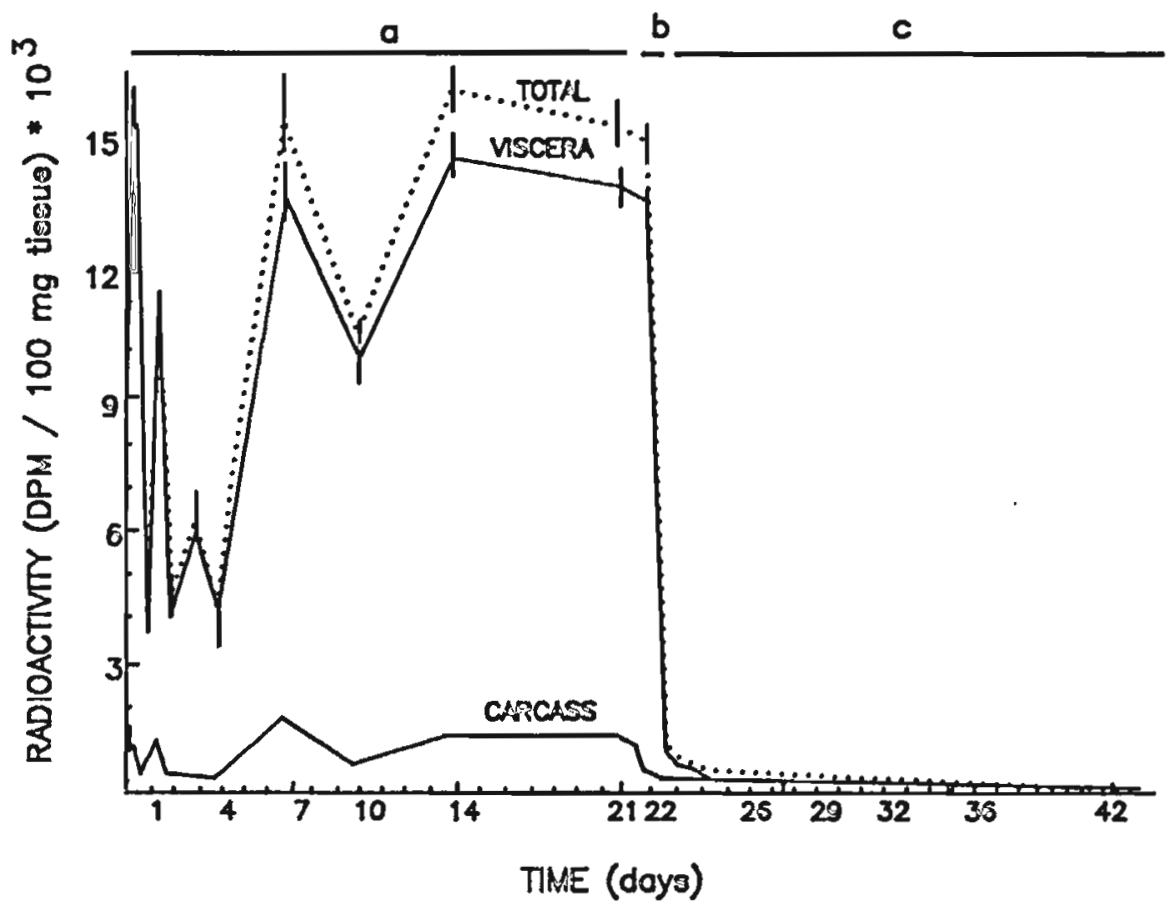

Figure 2. - Radioactivity (DPM/100 mg) present in carcass, viscera and whole body of sexually undifferentiated Oreochromis aureus fed a diet containing radiolabelled methyltestosterone for 21 days (redrawn from Goudie et al., 1986).

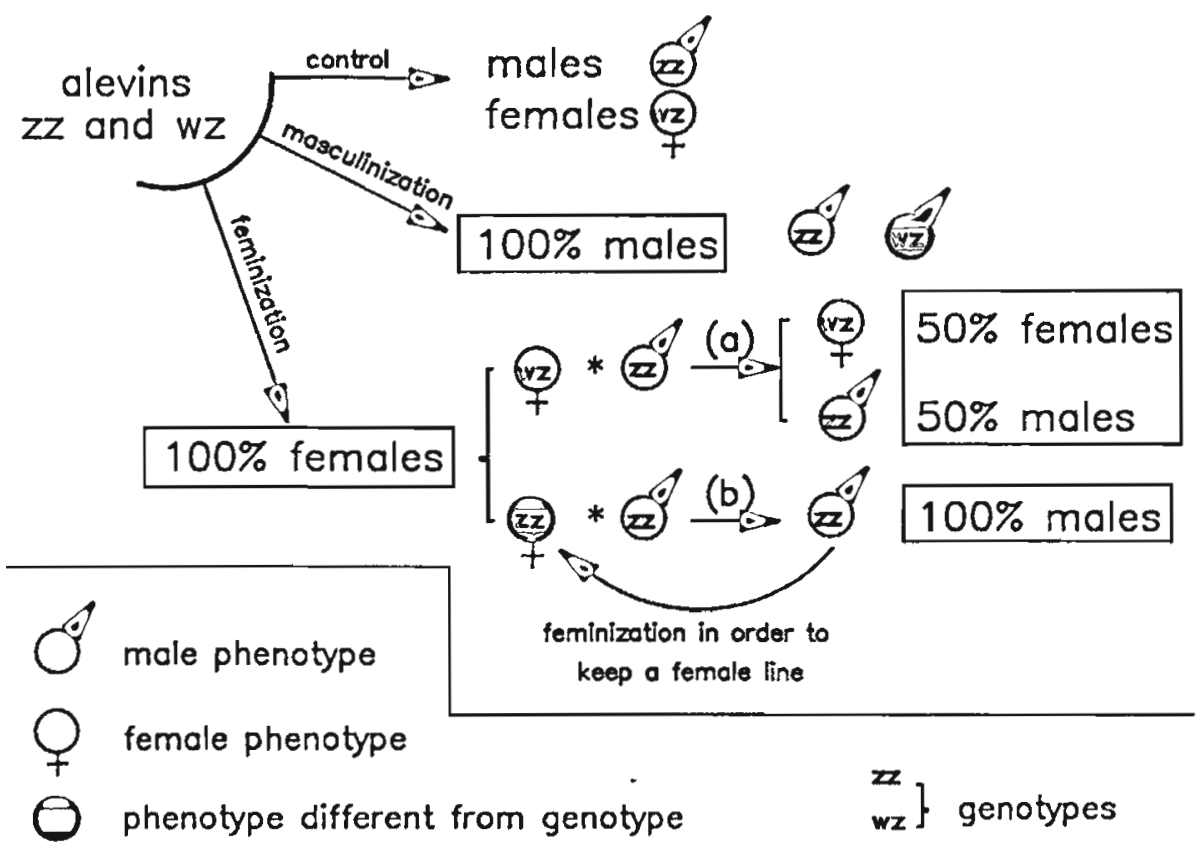

Figure 3. - Theoretical protocol in order to obtain monosex populations in species with male bomogamety, such as Oreochromis aureus and O. hornorum (redrawn from Baroiller, 1988). 


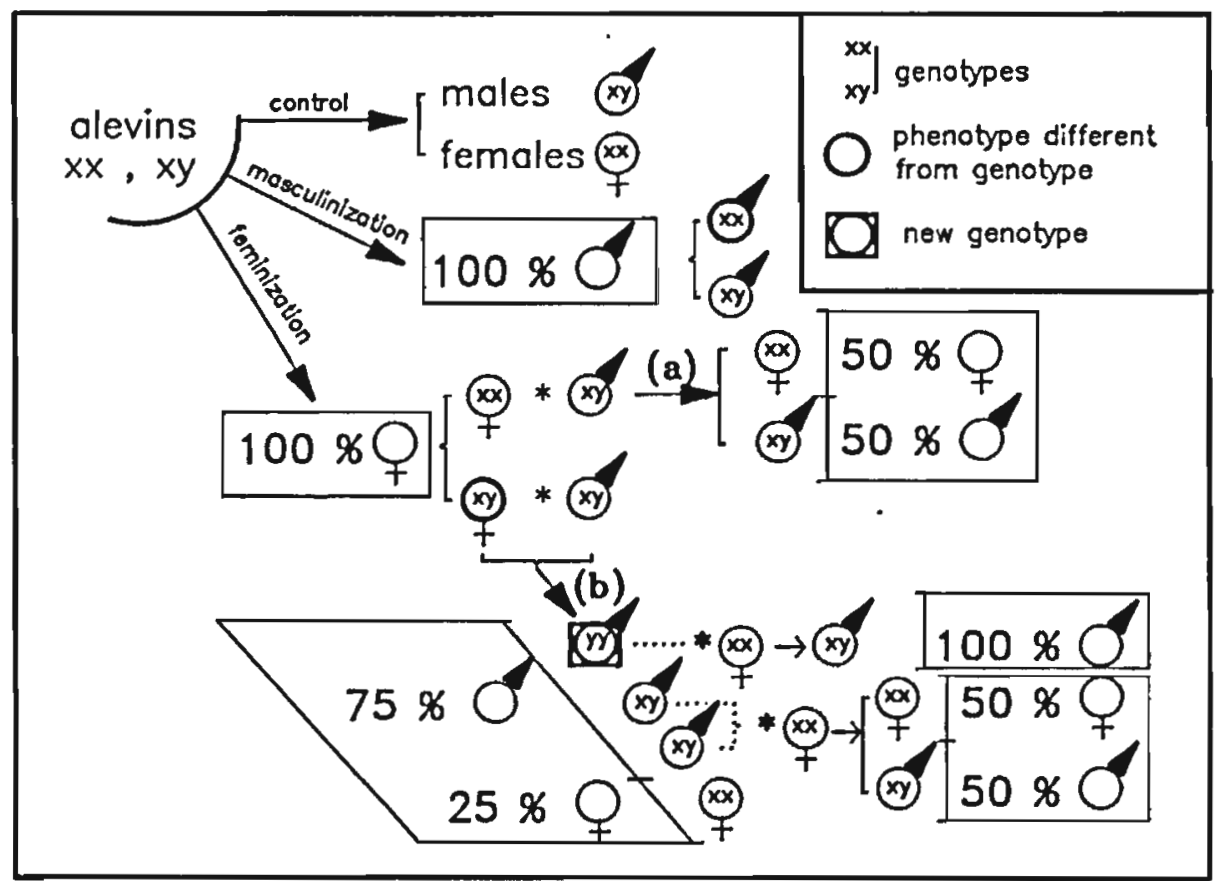

Figure 4. - Theoretical protocol in order to obtain monosex male populations in species with fermale homogamety, such as Oreochromis niloticus and $O$. mossambicus (redrawn from Baroiller, 1988).

were still histologically undifferentiated. When differentiation starts and while it is in progress, metabolites which are specific for each sex are identified. These do not systematically correspond to steroids which are used in the traditional treatments of hormone sex inversion; morcover, an androgen (testosterone) responsible for the male differentiation and of ocstrogens involved in that of the ovarian organization has not always been confirmed by these results. For example, testostcrone can be identified early in male as well as in female gonads. It can be expected therefore, that a better knowledge of the gonad endocrinal environment at these key moments could bring some improvements in the present sex control techniques and suggest new kinds of treatments. Particularly for $O$. niloticus as wcll as for Salmo gairdneri, a derivative of androstenedione (11 $\beta$ OH $\Delta_{4}$ ) seems to be specific to hte early stages of the testicular ontogenesis. Yet, this steroid is capable of masculinizing a normal fry population with great efficiency in rainbow trout (Van der Hurk and Slof, 1981; Van den Hurk and Van Oordt, 1985); steroid allows to obtain a $100 \%$ male population from a set of 0 . niloticus which are genetically female XX (Baroiller et al., unpublished data). Compounds inhibiting the synthesis of some the above mentioned homrones could be used to perform in titro experiments in order to verify the hypothesis according to which female differentiation would result from the lack of key steroids, specific of the testicular ontogenesis. They also could be used to carry out in tivo rescarch on new and more reliable feminization techniques in such species as $O$. aurca with the aim of obtaining neofemale $\mathrm{ZZ}$ broodstocks. The latter would give $100 \%$ male offsprings without result from direct hormonal treatment.

\section{GAMIETOGENESIS}

For tilapias, gametogenesis has only been partially described (Dadzic, 1969; Hyder, $1970 a$ and $b$; Polder, 1971; Von Kraft and Peters, 1963; Ilodgkins and Man, 1978; Babiker and Ibrahim, 1979; Moreau, $1979 b$; Grier and $\Lambda$ braham, 1983; Smith and Halcy, $1987 ; 1988)$. It scems to take place in the same way as for the majority of teleosts which have been studied. For this species, since the classical stages of oogenesis and spermatogenesis have been the subject of excellent review's (Hoar, 1969; Dodd, 1972; Billard, 1986; also see Jalabert and Zohar, 1982), only the characteristics which are specific to tilapias will be mentioned.

The eggs of Tilapias can be classified in two categories according to the presence or absence of secretion of a sticky substance secreted by the granulosa layer around specialized filaments. This characteristic is linked to the parental behaviour of tilapias. In general, substrate spawning fish (genus Tilapia) are the only fish which have this type of secretion, contrary to mouth-brooding species (genus Oreochromis and Sarotherodon). However, two intermediate cases 
are particularly interesting as regards the study of the possible evolution of the substrate spawning group towards that of mouth-brooding fish: Sarotherodon galilaeus which does not immediately take the fertilized eggs back into its mouth (Fishelson, $1966 \mathrm{~b}$ ) and Tilapia discolour which transports the eggs layed in the nest in its mouth (participation of the male and female fish) and then lays and ventilates them on the substrate of a more protected zone (Owusu-Frimpong, 1987): both Sarotherodon galilaeus and Tilapia discolour have such adhesive structures.

As for other species having a well developed parental care behaviour, mouth-brooding Sarotherodon and Oreochromis spawn eggs which are less numerous (several hundreds per spawning) than those layed by substrate spawning fish (several thousands). The sizc, weight and number of eggs generally increase according to the size of femalc fish. Yet, for the same total spawning weight, the number of eggs which constitutes the spawning can vary in a significant way (Peters, 1963).

\section{REPRODUCTION RATE AND SOCIAL FACTORS}

It has already been mentioned in the introduction that the age at first maturity can vary to a great extent. Although genetic as well as environmental factors have been implicated (Hyder, 1970; Siddiqui, 1979), the lack of experiments does not allow yet to draw any conclusions on the nature of the determinism of this puberty.

Once they have reached sexual maturity, male and female fish are capable of undergoing successive reproduction cycles throughout the whole year, under optimal conditions. The role of external factors on the reproduction rhythms and on the intensity of gametogenic production are still very poorly known; however, various works have clearly demonstrated the importance of social factors in the reproduction of these cichlids.

In the absence of any social stimulus, an isolated Sarotherodon melanotheron female fish still repeats the sequence oviposition-mouth-brooding initiation at a few month intcrvals (Aronson, 1945; 1951). Three types of stimuli are generally considered to be involved:

- Brecding male and breeding female fish can cmit sounds; however these sounds seem to be linked to reproduction only for the male fish which cmit them from his nest (Rodman, 1966; Lanzing, 1974); femalc fish apparently only cmit sounds when they eat (Lanzing, 1974). Male sound stimulli appear sufficient to increase the oviposition frequency of 0 . mossambicus females which are isolated from other stimuli (Marshall, 1972).

- Visual stimuli from congeneric fish also affect the ovulation of mature females since for $O$. mossambicus, ovulation occurs more frequently for stimulated fish than for totally isolated animals. Such stimuli are cqually efficient when they come from male or from female fish (Silverman, $1978 a$ and $b$ ).

- The mature female fish could emit a pheromone type substance, thus activating the courting behaviour of the male fish which is already visually stimulated. Pheromonal substances relcased by ovulated females have been identified in other fish species (for review, see Slaccy et al., 1988 and 1987, and Staccy, 1987). In tilapias however, the likely involvement of pheromones is only supported by the obscrvation that the courting activity of a male fish significantly increases when the reproduction period for female lish approaches, if these are living in the same aquarium, but not if only visual and sound stimulus can be exchanged between male and females through adjacent aquarium (Silverman, $1978 a$ and $b$ ). These stimuli are all the more efficient since for Sarotherodon melanotheron (Aronson, 1945) as well as for O. mossambicus (Silverman, $1978 a$ and $b$ ), the reproductive activity is significantly increased for animals having an non-limited contact with one another than for those having only a visual contact. $A$ more detailed study (Silverman, $1978 a$ and $b$ ) which links these different social factors to a histological analysis of gonads, shows that visual contacts mostly seem to hasien ovulation of full-grown oocytes and that they have no clear influence on the oocyte development pace. On the contrary, non-visual stimuli appear to accelerate not only ovulation, but also the onset of vitellogenesis, thus affecting the overall duration of oocyte development through various steps of oogenesis. A better knowledge of the pheromones involved during reproduction of tilapias could allow to synchronize, or at least to group spawnings of female breeders.

Social factors linked to the reproductive behaviour can even have an indirect influence on growth. The aggresive behaviour linked to the choice of the nest location, on which depends the future efficiency of courting, is strongly corrclated with the relative size of male fish $O$. mossambicus placed together in a same large-sized aquarium. After 24 wecks, the initial and final sizes of male fish are negatively correlated; however, the hierarchy which has been initially acquired as regards the aggresivity and location of the nest has not been put into question. The most aggressive male fish which choose the best locations spend most of their time defending their nest and reproducing at the expense of their dict. The less aggressive male fish thus have more found which is casily accessible (Turner, 1986). Since it was established that steroid hormone treatments (specially androgen masculinizing treatments) administered during development influence bchavioral differentiation in S. mossambicus (Billy and Liley, 1985), it would be interesting to cvaluate the effect of this kind of treatments on the relative aggressivity of males and growth variability in fish farm conditions.

\section{IIORMONAL DETERMIINISM OF THE PARENTAL BEHAVIOR}

The reproductive efficiency of tilapias is greatly due to the parental care lavished on the progeny. 
Knowledge of the hormone determination of parental behaviours could allow to elaborate new techniques for the artificial control of reproduction. For fish as for other vertebrates, reproduction is controlled through the hypothalamus-hypophysis-gonad axis. The possible implication of a pituitary hormone, prolactin (PRL), in the regulation of parental behaviour has been suggested. Surprisingly, however, tilapias have still not been chosen for such analysis, in spite of their wide range of parental care behaviour, from substrate spawning to mouth-brooding. Indeed, for numerous Cichlids, fertilization is quickly followed up by a ventilation of the spawned eggs by means of alternative movements of the pectoral fin which is precisely oriented towards the eggs. Ovine prolactin is capable of inducing as well as maintaining such behaviour when normal external stimulus (such as the presence of cggs or of a nest) are lacking. The intensity of this behaviour which is linked to a clear decrease in the fish agressivity and appetite depends on the prolactine dose which has been administrated. From a minimum threshold dose up to an average value, the duration and intensity of ventilation increase significantly; then, when doses are further increased, this behaviour is progressively inhibited and eventually stops completely. At least four Cichlids react this way to the injection of this ovine hypophysis hormone: Symphysodon aequifasciata axelrodi, Pterophyllum scalare and Aequidens pulcher (Blüm and Fiedler, 1965; Blüm, 1966) as well as Chromis chromis (non-published data quoted by Blüm, 1968). A Labrid fish, Crenilabus ocellatus had already be reported to react in such a way to prolactin (Fiedler, 1962). Although no similar experiment in tilapias has been reported so far, a tilapia prolactin has been purified (Blüm, 1973) by using bioassays performed in the Discus (Symphysodon sp.) based on the above mentioned behavioural effects and also on histiotropic effects, i.e. an increase in the number of mucus cells and mucus production by the brooders' skin (this mucus appears to be used as a food by the fry of this species).

Other "prolactins" from tilapias, now recently isolated and purified on the basis of biochemical criteria, should thus be tested within the same species to look for a possible effect on the behaviour of substrate spawning or mouth-brooding fish.

Further knowledge of the hormone determinism of this behaviour could allow to try and delay, or even stop the ovarian development or inhibit any parental care so as to avoid fry proliferation.

As a matter of fact, a recent study in 0 . mossambicus (Smith and Halcy, 1987) established some relationship between the duration of the successive eggs and fry mouth-brooding periods and the duration of the ovarian cycle ( $\mathrm{fig} .5$ ). In that species, a continuous mouth-brooding period is normally observed till the 15th day post-fertilization (d.p.f.) at about $27^{\circ} \mathrm{C}$; then, during an additional 10 day period (till the 25th d.p.f.), mouth-brooding is discontinuous: the fry swims near their mother up until the slightest signal on her part which immediatly gathers them back into its buccopharyngeal cavity. In a few cases, the mother rejects the eggs the day after fecundation. This latter situation can also be provoked by removing the eggs from the mothers mouth 1 d.p.f. A histological study shows that a post ovulatory follicular tissue is persisting differently in these two kinds of situation. Ten days after the egg removal or loss, this structure begins to degenerate and quickly disappears; on the contrary, such a structure persists up until the 25th day after fecundation for mouth-brooding female fish. This cellular mass can be compared to some extent to the corpus luteum of mammals, since it exhibits the main usual ultrastructural and histochemical characteristics of steroid producing cells, at this moment of the cycle. These steroidogenic potentialities can be observed as long as this tissue persists: however, the developing follicles of the following wave quickly show a potential activity which is first equal to-around the 6th d.p.f.-, and then even superior to that of post-ovulatory follicles. All these gonadal changes result in a rapid ovarian development for non-brooding female fish, which leads to ovulation taking place 25 d.p.f.; on the contrary, they result in a slower cycle with an ovulation taking place 40 d.p.f. for female fish having a normal behaviour. Parental care is thus associated with a 15 day inhibition of the oocyte development. The presence of eggs and then fry in the buccopharungeal cavity scems to determine the persistence of the post ovulatory follicles and its secretion as well as the progress of oogenesis. These authors (Smith and Haley, 1988) measurcd the concentrations of plasma steroids for both categories of animals and showed some difference between the respective endocrinological profiles, as far as ocstradiol-17 $\beta$ and testosterone are concerned: quantitatively comparable levels were only reached after a 5 day delay for brooding female fish compared to non-brooding females.

The use of appropriate steroids in order to mimic such physiological situations should be explored as a possible way either to inhibit the ovarian development or to disrupt the parental behaviour. Even if attempts are made to avoid reproduction of cultured tilapias in order to eliminate overcrowding and nanism, massive productions of fry, homogencous in age and size, are also quite desirable for a better management of fish farms. This should be particularly interesting, as far as two practical problems of commercial fish farming are concerned:

- When the production of monosex populations by means of hormonal inversion is required, the cfficiency of the treatment depends, among other necessary conditions, on the initial age of the fry which should be as low and homogeneous as possible. If reproduction is not synchronized, it is presently indispensable to keep very numerous brooders and then to sort out the fry according to their size.

- In certain types of fish farms, the lack of synchronization can lead fish farmers to carry out the first alevin harvesting only after 1.5 to 2 months, 


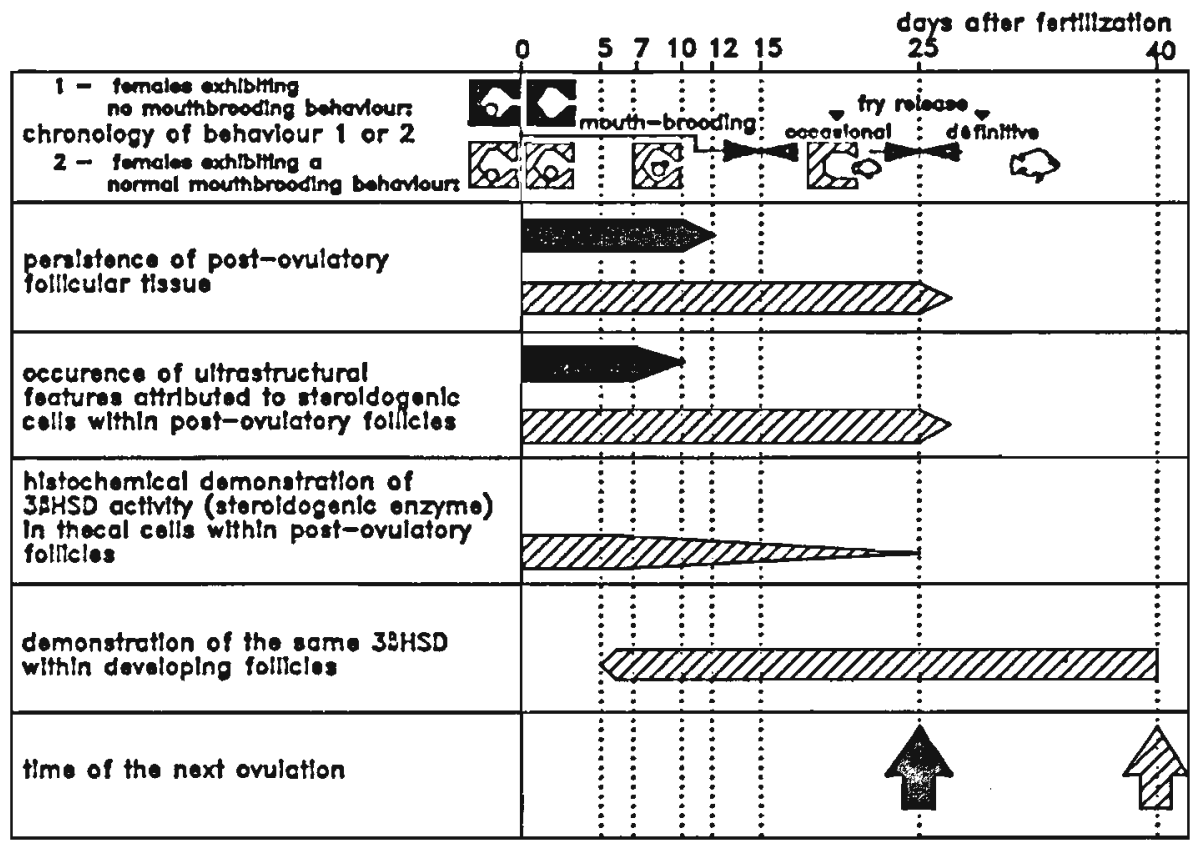

Figure 5. - Evolution of cytological and histochemical characteristics of ovarian follicles, and duration of the ovarian cycle, in relationship with cither normal or abnormal mouthbrooding behaviour in Oreochromis mossambicus (schematic representation of data reported by Smith and Haley, 1987).

when the greatest number of alevins can usually be obtained. However, the surface swimming behaviour of fry and the harvesting methods allow the fish which were born.first (1 to 2 weeks after the introduction of breeding fish) to escape this first catch. Still, juve-

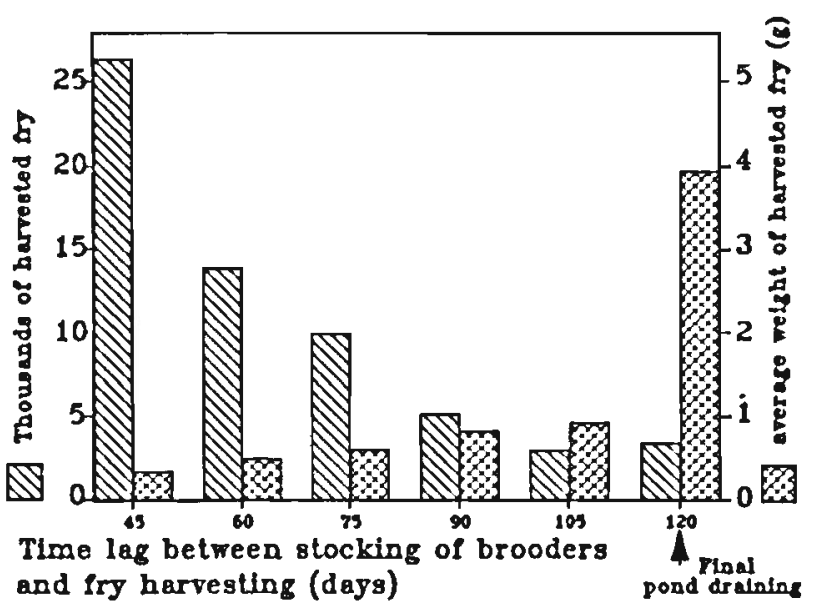

Figure 6. - Evolution of the number and arerage weight of harvested Oreochromis niloticus fry as a function of successive harvests. Mean data out of ten $350 \mathrm{~m}^{2}$ ponds, cach containing 60 male and 180 female brooders (drawn from data reported by Lazard et al., 1988). niles are efficient predators for younger fish, even more than breeding fish. A progressive yicld decrease ( $f i g .6)$ can thus be noticed for the following catches performed in the same production structure (Lazard et al., 1987). The simultancous increase in the average weight of alevins which have been caught reflects the partial harvest of predator juveniles which have finally all been caught when the final draining of the pond was made (6th sample).

\section{CONCLUSION}

The analysis of specific features of tilapia's reproductive physiology brings to the fore two main paths of research which are to be studied for a better reproduction control.

The modification of normal sex differentiation by exogenous steroids presently remains the best way to avoid reproduction and to bencfit by a growth potential of all individuals which are directly or indirectly oriented towards a male phenotype. The relatively empirical approach which has been carried out up until now allowed to quickly lead up to efficient masculinizing treatments. However, it is necessary to make a datailed study of the endocrinal determinism of differentiation as regards the possible indirect use of hormones, since the feminization process-which represents one of the main tools to be used to this 
end -, is still very difficult to implement. Moreover, a better knowledge of the gonad hormone environment during its differentiation should allow to use specific inhibitors of the enzymatic activities as new types of treatments. Finally such a study seems to be necessary in order to make a detailed analysis of the influence of epigenetic factors on differentiation.

The reproductive efficiency of tilapias essentially results from the importance of the behaviours before and after spawning. New tools for the control of reproduction can be expected to be developed from a better knowledge of the determinism of these different behaviours. The natural inhibition of the ovarian development during the mouth-brooding period and the likely involvement of pheromones in the regulation of reproductive behaviour during spawning suggest possible rescarch fields aimed at controlling tilapia reproduction by inhibiting disorderly fry production and favoring synchronous spawning for mass production of homogeneous fry.

\section{REFERENCES}

Aronson L. R., 1945. Influence of the stimuli provided by the male Cichlid fish $T$. macrocephala on the spawning frequency of the femalc. Physiol. Zool., 18, 403-415.

,- 1951 . Factors influencing the spawning frequency in the remale Cichlid fish Tilapia macrocephala (Bleeker). Trans. N. Y. Acad. Sci., 2, 33-42 (also in Amer. Mus. Notit., 1484, 1-26).

Arrignon J., 1969. L'élevage de Tilapia mossambica comme animal de laboratoire. Verh. Int. Ver. Theor. Angew: Limnol., 17, 650-661.

Babiker M. M., H. Ibrahim, 1979. Studies on the biology of reproduction in the Cichlia Tilapia nilotica (L.): gonadal maturation and fecundity. J. Fish. Biol., 14, 437-448.

Bard J., P. de Kimpe, J. Lemasson, P. Lessent, 1974. Manucl de Pisciculture tropicale. CTFT Nogent-surMarne, $209 \mathrm{p}$.

Baroiller J.-F., 1988. Étude corrélée de l'apparition des critères morphologiques de la différenciation de la gonade et de ses potentialités stéroïdogènes chez Oreachromis niloticus. Thèse dr., Univ. Pierre-et-Maric-Curic, Paris, $70 \mathrm{p}$.

Baroiller J.-F., A. Fostier, B. Jalabert, 1988. Precocious steroidogenesis in the gonads of Oreochromis niloticus during and after sexual differentiation. In: Reproduction in fish Basic and applied aspects in endocrinology and genetics, Y. Zohar, B. Breton Eds., Les Colloques de IINRA, 44, 137-141.

Billard R., 1986. Spermatogenesis and spermatology of some teleost fish species, Reprod. Nutr. Der., 26, 877920.

Billy A. J., N. R. Liley, 1985. The effects of early and late androgen treatments on the behavior of Sarotherodon mossambicus (Pisces: Cichlidae). Horm. Behat., 19, 311. 330.

Blüm V., 1966. Zur hormonalen Steuerung der Bruteflege einiger Cichliden. Zool. Jb. Physiol., 72, 26ł-294.
- 1968. Immunological delermination of injected mammalian prolactin in Cichlid fishes. Gen. Comp. Endocr., 11, 595-602.

- 1973. Experimente mit teleosteen Prolaktin. Zool. Jahrb (Allg. Zool. Physiol. Tiere), 77, 335-347.

I3lüm V., K. Fiedler, 1965. llormonal control of reproductive behavior in some Cichlid fish. Gen. Comp. Endoc., 5, 186-196.

Bruton M. N., B. R. Allanson, 1974. The growth of Tilapia mossambica Peters (Pisces Cichlidae) in Lake Sibaya, South Africa. J. Fïsh. Biol., 6, 701-715.

Bruton M. N., R. E. Boltt, 1975. Aspects of the biology of Tilapia mossambica Peters (Pisces, Cichlidae) in a natural freshwater lake (Lake Sibaya, South Africa). J. Fish. Biol., 7, 423-446).

Chen F. Y., 1969. Preliminary studies on the sex-determining mechanism of Tilapia mossambica Peters and T. Hornorum Trewavas. Verh. Int. Ver. Their. Angew, Limnol., 17, 719-724.

Chervinski J., S. Rothbard, 1982. An aid in manually sexing Tilapia. Aquaculture, 26, 389.

Clemens H. P., T. Inslee, 1968. The production of unisexual broods by Tilapia mossambica sex reversed with methyltestosterone. Trans, Am. Fish. Soc, 97, 18-21.

Dadzie S., 1969. Spermatogenesis and the stages of maturation in the male Cichlid fish Tilapia mossambica. J. Zool., 159, 399-403.

Dadzic S., B. C. C. Wangila, 1980. Reproductive biology, length-weight relationship and relative condition of pond raised Tilapia zilii (Gervais). J. Fish. Biol., 17, 243-253.

Dodd J. M., 1972. The endocrine regulation of gametogenesis and gonad maturation in fishes. Gen. Comp. Endocrinol., Suppl. 3, 675-687.

Eyeson K. N., 1983. Stunting and reproduction in pondreared Sarotherodon melanotheron. Aquaculture, 31, 257 267.

Fiedler K., 1962. Die Wirkung von Prolaktin auf das Verhalten des lippfishes Crenilabrus ocellatus (Forskal), Zool. Jb. Physiol., 69, 609-620.

Fishelson L., 1966. Cichlidac of the genus Tilapia in Israel. Bamidgeh, 18, 67-80.

Fotherby K., F. James, 1972. Metabolism of synthetic steroids. In: Advances in steroid biochemistry and pharmacology, M. H. Briggs, G. A. Christie Eds., 3, Academic Press. New York, 67-165.

Fryer G., T. D. lles, 1972. The Cichlid fishes of the great lakes of Africa: their biology and evolution. TFH Publ., Neptune City. New Jersey.

Goudic C. A., W. L. Shelton, N. C. Parker, 1986a. Tissue distribution and climination of radiolabelled methyltestosterone fed to sexually indifferentiated blue Tilapia. Aquaculture, 58, 215-226.

$-1986 b$. Tissue distribution and elimination of radiolabelled methyltestosterone fed to adult blue Tilapia. Aquaculture, 58, 227-240.

Grier J. H., M. Abraham, 1983. A model for testicular recrudescence in Oreochromis aureus. In: Proc. Int. Symp. Tilapia in Aquaculture, Nazarcth, Isracl, 200-209.

Guerrero R. D., 1975. Use of androgens for the production of all-male Tilapia aurea (Stcindachner). Trans. Am. Fish. Soc., 2, 342-348. 
-, 1982. Control of Tilapia Reproduction. In: The biology and culture of Tilapia, R. S. V. Pullin, R. H. LoweMicConnell Eds., ICLARM, Manila, Philippincs, 309. 316.

Hanson T. R., R. O. Smitherman, W. L. Shelton, R. A. Dunham, 1983. Growth comparison of monosex tilapia produced by separation of sexes, hybridization and sex reversal. In: Procecdings of the International Symposium on Tilapia in Aquaculture, L. Fishelson, Z. Yaron Eds., Tcl $\Lambda$ viv University, Tel Aviv, 570-579.

Hepher B., Y. Pruginin, 1982. Tilapia culture in ponds under controlled conditions. In: The biology and culturc of Tilapia, R. S. V. Pullin, R. H. Lowe-McConnell Eds., ICLARM, Manila, Philippines, 185-203.

Hickling C. F., 1960. The Malacca Tilapia hybrids. J. Genet., 57, 1-10.

-, 1968. Fish hybridization. FAO Fish Rep., 44, 1-11.

Hoar WV. S., 1969. Reproduction. In: Fish Physiology, IV. S. Hoar, D. J. Randall Eds., A3, Academic Press, New York, 1-72.

Hodgkins I. J., H. S. H. Man, 1978. Reproductive biology of Sarotherodon mossambicus (Cichlidae) in Plover Cove reservoir, Hong Kong. Entiron. Biol. Fish., 3, 287-292.

Hopkins K. D., W. L. Shelton, C. R. Englc, 1979. Estrogen sex reversal of Tilapia aurea. Aquaculture, 18, 263-268.

Hunter G. A., E. M. Donaldson, 1983. Hormonal sex control and its application to fish culture. In: Fish l'hysiology, W. S. Hoar, I). J. Randall, E. M. Donaldson, Eds., 9B, Academic 1'ress, New York, 223-303.

Hyder M1., $1970 \mathrm{a}$. Gonadal and reproductive patterns in Tilapia leucosticta (Telcostci: Cichlidac) in an equatorial lake: Lake Naivaska (Kenya). J. Zool., 162, 179-195.

-, $1970 \mathrm{~b}$. Ilistological studies on the testes of pond specimens of Tilapia nigra (Gunther) (Pisces: Cichlidae) and their implications in the pituitary testis relationship. Gen. Comp. Endocr., 14, 198-211.

Jalabert B., J. Morcau, P. Planquette, R. Billard, 1974. Determinisme du sexe chez Tilapia macrochir et Tilapia nilotica. Action de la méthyltestostérone dans l'alimentation des alcvins sur la différenciation sexuelle; proportion des sexes dans la descendance des mâles «inversés". Ann. Biol. anim. Bioch. Biophys., 14, 4 B, 729-739.

Jalabert B., Y. Zohar, 1982. Reproductive physiology in Cichlid Fishes with particular reference to Tilapia and Sarotherodon. In: The biology and culture of Tilapia, R. S. V. Pullin, R. II. I.owe-MicConnell Eds, ICLARM, Manila, Philippincs, 129-140.

Johnstone R., D. J. Macintosh, R. S. Wright, 1983. Elimination of orally administered $17 x$-methyltestosterone by Oreochromis mossambicus (Tilapia) and Salmo gairdncri (rainbow trout) juveniles. Aquaculiure, 35, 249-257.

Lanzing W. J. R., 1974. Sound production in the Cichlid Tilapia mossambica P'eters. J. Fish. Biol., 6, 341-347.

Lazard J, 19\$0. Le développement de la pisciculture intensive en Cóte-d'Ivoire. Fxemple de la ferme piscicole pilote de Natio-Kobadara (Khorhogo). CTFT, Notes et Documents sur la Péche et la Pisciculture, 21, 1-44.

-, 1984. L'élevage du Tilapia en Afrique. Données techniques sur la pisciculture en étangs. Bois et Forĉts des Tropiques, 206, 33-60.

Lazard J., P. Morissens, P. Parrel, 1987. Artisanal aquaculture of tilapia in W'cst Africa: comparative analysis of different culture systems and their development level. In: Second international Symposium on Tilapia in Aquaculture (ISTA II), Bangkok, Thailand, March 1987.

Legendre M., 1986. Inlluence de la densité de l'élevage monosexe et de l'alimentation sur la croissance de Tilapia guineensis et de Sarotherodon Melanotheron ćlevés en cage enclos en lagune Ebrié (Cöte-d'Ivoire). Ret. Hydrobiol. Trop., 19, 19-29.

Liu C., 1977. $\Lambda$ spects of reproduction and progeny testing in Sarotherodon aurcus (Steindachner). MSc. thesis, Auburn Univ., Alabama, $42 \mathrm{p}$.

Lovshin L. L., 1982. Tilapia hybridization. In: The biology and culture of Tilapia, R. S. V. Iullin, R. H. LoweMcConnell Eds., ICLARM, Manila, Philippines, 279. 308.

Lowe-McConnell R. H., 1958. Observations on the biology of Tilapia nilotica L. in East African Waters. Ret. Zool. Bot. Africa, 57, 129-170.

-, 1959. Brecding behavior patterns and ecological differences between Tilapia species and their significance for evolution within the genus Tilapia (Pisces, Cichlidae). Proc. Zool. Soc. London, 132, 1-30.

-, 1982. Tilapia in Fish Communities. In: The biology and culture of Tilapia, R. S. V. Pullin, R. H. Lowe-1fcConncll Eds., ICLARM, Manila, Philippines, 83-113.

Loya L., L. Fishelson, 1969. Ecology of fish brecding in brackish water ponds near the dead sea (Israel), J. Fish. Biol., 1, 261-278.

Marshall J. A., 1972. Influence of male sound production on oviposition in female Tilapia mossambica (lisces: Cichlidac). Bull. Ecol. Soc, Am, 53, 29.

McBay L. G., 1961. The biology of Tilapia nilotica (Linnaeus). Proc. Annu. Conf. South-East. Assoc. Game Fish Comm., 15, 208-218.

McGeachin R. B., E. H. Robinson, IV. H. Neil, 1987. Effect of fecding high levels of androgens on the sexratio of Orcochromis aureus. Aquaculture, 61, 317-321.

Mćlard C., 1986. Recherches sur la biologic d"Orcochromis (Tilopia) niloticus L. (Pisces: Cichlidae) en élevage expérimental: reproduction, croissance, bioćnergétique. Cah. Ethol. appl., 6, 1-224.

Mélard C.. J. C. Philippart, 1981. La production de Tilapia de consommation dans les rejets industricls de l'cau chaude en Belgique. Cah. Elhol. appl., 1 (suppl. 2), $7-$ 122.

Mires D., 1982. A study of the problems of the mass production of hybrid Tilapia fry. In: The biology and culture of Tilapia, R. S. V. Pullin, R. H. Lowe-McConnell Eds., ICLARM, Manila, Philippines, 317-329.

Morcau J., 1979. Biologie et évolution des peuplements de Cichlidés (Pisces) introduits dans les lacs malgaches d'altitude. These INP, Toulouse, France, $301 \mathrm{p}$.

Nakamura M., M. Iwahashi, 1982. Studies on the practical masculinization in Tilapia nilotica by the oral administration of androgens. Bull. Jap. Soc. Fish., 48, 763-769.

Obi A.. W. L. Shelton, 1983. Androgen and estrogen sex-reversal in Tilapia hornorum. In: Procedings of the International Symposium on Tilapia in Aquaculture, L. Fishelson, Z. Yaron Eds., Tel Aviv Univ., Isracl, 165-173.

Owusu-Frimpong M., 1987. Brecding behavioral pattern of the lake fish Tilapia discolour Gunther (Teleostei, Cichlidac) in captivity. J. Hish. Biol., 30, 1-5. 
Owusu-Frimpong M., B. Nyjhar, 1981. Induced sex-reversal in Tilapia nilotica (Cichlidae) with methyltestosterone. Hydrobiologia, 78, 157-160.

Perrone M., T. M. Zaret, 1979. Parental care patterns of fishes. Am. Nat., 113, 351-361.

Peters H. M., 1963. Eizahl, Eigewicht und Gelegeentwicklung in der Gattung Tilapia (Cichlidae, Teleostei). Int. Rev. Gesant. IJ drobiol., 48, 547-576.

Philippart J. C., J. C. Ruwct, 1982. Ecology and distribution of Tilapia. In: The biology and culture of Tilapia, R. S. V. Pullin, R. H. Lowe-McConnell Eds., ICLARM, Manila, Philippines, 15-59.

Polder J., 1971. On gonads and reproductive behavior in the Cichlid fish Aequidens portalegrensis (Hensel). Neth. J. Zool., 21, 265-365.

Pruginin J., 1967. Report to the governemnt of Uganda on the experimental fish culture project in Uganda, 19651966. UNDP/FAO, Report NOTA 2446.

Pruginin J., S. Rothbard, G. Wohllarth, A. Halevy, R. Moav, G. llulata, 1975. All male broods of Tilapia nilotica $\times$ T. aurea hybrids. Aquaculture, 6, 11-21.

Reinboth R., 1970. Intersexuality in fishes. $1 \mathrm{fcm}$. Soc. Endocr., 18, 515-544.

Rodman D. T., 1966. Sound production by the African Cichlid Tilapia mossambica. Ichthyologia, 38, 279-280.

Rothbard S., 1979. Observations on the reproductive behavior of Tilapia zilit and several Sarotherodon sp. under aquarium conditions. Bamidgeh, 31, 35-43.

Rothbard S., B. Moav, Z. Yaron, 1987. Changes in steroid concentrations during sexual ontogenesis in Tilapia. Aquaculture, 61, 59-74.

Rothbard S., Y. Pruginin, 1975. Induced spawning and artificial incubation of Tilapia. Aquaculture, 5, 315-321.

Ruwet J. C., 1962. La reproduction des Tilapia macrochir (Blgr) et Tilapia melanopleura (Dim.) au lac de barrage de la Lufira (Haut Katanga). Rev. Zool. Bot. Afr., 66, 244-271.

Ruwet J. C., J. Voss, L. Hanon, J. C. Micha, 1976. Biologie et élevage du Tilapia. In: Symposium on Aquaculture in Africa, FAO/CJFA. Tech. Pap., 4 (suppl. 1), 332-364.

Shaw E. S., L. R. Aronson, 1954. Oral incubation in Tilapia macrocephala. Bull. Am. Mus. Nat. Hist., 103, 381-415.

Shell E. WV., 1967. Relationship between rate of growth and rate of conversion in feeding trials with two species of tilapia, Tilapia mossambica Peters and Tilapia nilotica linnaeus. FAO. Fish. Rep., 4\&, 411-415.

Shelton IV. L., K. D. Hopkins, G. L. Jensen, 1978. Use of hormones to produce monosex tilapia for aquaculture. In: Culture of Exotic Fishes Symposium Procecdings, Fish culture section, R. O. Smitherman, W. L. Grover Eds., Am. Fish. Soc. Auburn University, Alabama, USA., 10-33.

Shelton IV. L., R. D. Guerrero, J. Lopez-Mfacias, 1981. Factors afrecting androgen sex reversel of Tilapia aurca. Aquaculture, 25, 59-65.

Siddiqui A. Q., 1979. Reproductive biology of Tilapia silii (Gervais) in Lake Naivaska, Kenya. Entiron. Biol. Fishes, 4, 257-262.

Silverman II. I., 1978a. Effects of different levels of sensory contact upon reproductive activity of adult male and female Sarotherodon (Tilapia) mossambicus (Peters), Pisces: Cichlidae. Anim. Behar., 26, 1081-1090.

,$- 1978 b$. The effects of visual social stimulation upon age of first spawning in the mouth-brooding Cichlid fish Sarotherodon (Tilapia) mossambicus (Pcters). Anim. Behat., 26, 1120-1125.

Smith C. J., S. R. Haley, 1987. Evidence of steroidogenesis in post ovulatory follicles of the tilapia, Oreochromis mossambicus. Cell Tissue Res., 247, 675-687.

,- 1988 . Steroid profiles of the female Tilapia Oreochromis mossambicus, and correlation with oocyte growth and mouth-brooding behavior. Gen. Comp. Endocr., 69, 8898.

Stacey N. E., 1987. Roles of hormones and pheromones in fish reproductive behavior. In: Psychobiology of Reproductive Behavior: An Evolutionary perspective. D. Crew Ed., Prentice Hall, 1987, chap. 2, p. 28-60.

Stacey N. E., A. L. Kyle, N. R. Lilcy, 1986. Fish reproductive pheromones. In: Chemical Signals in Vertebrates IV. D. Duvall, D. Muller-Schvarze, R. M. Silverstein Eds., Plenum Press, 117-133.

Stacey N. E., P. W. Sorensen, J. G. Dulka, G. J. Van der Kraak, T. J. Hara, 1987. Teleost sex pheromones: recent studies on identity and function. In: Proceedings of the third international Symposium on the reproductive physiology of fish, St. John's, Newfoundland, Canada. D. R. Idler, L. W. Crim, J. M. Walsh Eds., 150-153.

Tayamen M. M., IV. L. Shelton, 1978. Inducement of sex reversal in Sarotherodon niloticus. Aquaculture, 14, 349. 354.

Turner G. F., 1986. Territory dynamics and cost of reproduction in a captive population of the colonial nesting mouth-brooder Oreochromis mossambicus (Peters). $J$. Fish. Biol., 29, 573-587.

Van der Hurk R., J. G. D. Lambert, J. Peute, 1982. Stercoidogenesis in the gonads of rainbow trout fry Salmo gairdneri before and after the onset of gonadal sex differentiation. Reprod. Nutr. Detelop., 22, 413-426.

Van den Hurk R., G. A. Slof, 1981. A morphological and experimental study of gonadal sex differentiation in the rainbow trout, Salmo gairdneri. Cell Tissue Res., 218, 487-497.

Van den Hurk R., W. Van Oordt, 1985. Effects of natural androgens and corticosteroids on gonad differentiation in the rainbow trout, Salmo gairdneri. Gen. Comp. Endocr., 57, 216-222.

Von Kraft A., H. M. Peters, 1963. Vergleichende Studien über die Oogenese in der Gattung Tilapia (Cichlidae, Teleostei). Z. Zellforsch. Mikrosk. Anat., 61, 434-485.

Yamamoto T., 1953. Artilicially induced sex reversal in genotypic males of the medaka (Oryzias latipes). J. Exp. Zool., 123, 571-594.

-, 1958. Artificial induction of functional sex reversal in genotypic females of the medaka (Oryzias latipes). $J$. Exp. Zool., 137, 227-262.

-, 1969. Sex differentiation. In: Fish Physiology, W. S. Hoar, D. J. Randall, E. M. Donaldson Eds., Academic Press, New York, 3, 117-175. 